\title{
SURVEY
}

\section{Beyond Chesnaux: Workers, Class, and the Socialist Revolution in Modern China}

\author{
A RIF DIRLIK
}

The history of urban labor in modern China is deeply entangled in questions of the communist revolution, and so are the interpretations of that history. If we leave out two important accounts of labor in Chinese written by organizers before the I960s, studies of labor in modern China only have a four-decade history. ${ }^{\mathrm{I}}$

There has been a I 80 -degree shift during this period in interpretations of labor and the relationship of laborers to the revolution and the communist regime. A fully conscious urban proletariat of an earlier day, forged in the struggles of the I920s and I940s, has been replaced in scholarship by workers whose class-consciousness (if not consciousness of class) was nonexistent or was highly compromised, who were deeply divided by varieties of spatial and social boundaries, and were still at the mercy of "traditional" organizational and cultural practices that they brought from their mostly rural backgrounds, from which they were yet to be weaned. No less important has been the shift in interpretations of the relationship between the workers and the Communist Party toward greater stress on divergence and conflict of interest, especially for the years after the establishment of the People's Republic of China. We may be more prepared than before to be suspicious of claims to a coincidence of interest between the Party and the workers even during the revolutionary years, with currently accumulating evidence of the severe exploitation and abuse of workers as one of the last remaining "workers' states" seeks to reinvent itself as global capitalist powerhouse.

I. I am referring here only to works that deal with the labor movement. As Ming K. Chan has pointed out, there were rich sources for the investigations of labor conditions and, after I949, accumulating collections of memoirs, etc. which have been very valuable in later years (Chan, Historiography). References to organizers' accounts are to Deng Zhongxia, Zhongguo zhigong yundong jianshi (A Concise History of the Chinese Labor Movement), [hereafter Concise History], and, Ma Chaojun, Zhongguo laodong yundong shi (History of the Chinese Labor Movement), [hereafter Labor Movement]. 
I will discuss below some of the intellectual and political implications of these shifts. There are good reasons for these changes in interpretation in terms of the evidence that has become available over the years. The question of class has been a subject of debate among Chinese radicals themselves. It has been apparent for quite some time now that since there could be no denial of the overwhelmingly rural and peasant content of the revolution, claims to communism could be sustained only by establishing the presence of a working class conscious of its class interests and mission - and supportive, therefore, of the communist revolution. A working class had to be invented even if it did not exist. Whether or not workers in China constituted a class in any meaningful sense has been central to the problematic of labor history. The question of community of interests between the Party and the working class, too, was raised early on, first by the anarchists, and subsequently by the Trotskyist opposition following the internal Party split after the debacle of urban revolution in 1927. While there is considerable room for disagreement over this question where it refers to the revolutionary years, the evidence is much more direct for the years the Party has been in power.

I suggest here, however, that in spite of the much broader and deeper evidential base they may claim, contemporary interpretations of labor in the Chinese revolution need to retain earlier interpretations as a frame of reference, if only as a critical reminder that current interpretations too are products of a particular historical conjuncture, which shapes the questions we ask of the past and the way we read the answers. The fall of socialism and the assault on workers globally are crucial to grasping the particular contradictions of this conjuncture. So is a retreat from modernity, and a downgrading of rationalist readings of social processes that informed both socialism, and the analysis of classes - which has led to a privileging of particular cultural legacies over the universally transformative forces of capitalist modernity. These reinterpretations are undertaken in academic guise, but we need to be cognizant also of their politics - and political implications.

\section{THE QUESTION OF THE WORKING CLASS}

While many works on modern Chinese politics refer to labor and labor issues, my concern here is mainly with those works that take labor and labor movements as their focus; works that represent what we might describe as labor-centered approaches to modern Chinese history. ${ }^{2}$ Much

2. For the benefit of the reader, I have sought to be as comprehensive as possible with booklength studies on Chinese labor (even though I refer at length only to a few works that I think have been innovative and influential), and also to illustrate issues raised in the discussion. Arguably, and possibly for good reasons, there is no work with which I am familiar that offers a comprehensive account of labor and labor politics in China - covering the whole national 
more so than any works by Chinese communist authors on labor, it is Jean Chesneaux's account of Chinese labor in the I920s that has provided the classic Marxist account of issues of class and socialism in China. A pathbreaking work in vision, boldness of interpretation, and scholarship, The Chinese Labor Movement has set the agenda for writing about the history of labor in China, posed the questions that historians of Chinese labor continue to struggle with, and illustrates, possibly for the very same reasons, the teleologies of class and socialism that guided an earlier interpretation of labor.

Chesneaux's work covered the period 1919-1927, which witnessed the high tide of urban revolution in China, the launching of an intellectual and cultural revolution, the establishment of the Communist Party, and the entry of labor into politics in a significant way. The Communist Party and the labor movement grew in tandem in these years. No matter how far one might go in questioning the "class-ness" of Chinese workers, or the relationship between the Party and the workers, nobody has suggested that the growth of one may be comprehensible without reference to the growth

territory over the period (I 890 s to the present). There certainly remains much territory to be investigated where labor history is concerned. On the other hand, while few in number, the works that are available nevertheless cover much ground both geographically, and in terms of the issues involved. In addition to works that aspire to national scope (A. Chan, China's Workers Under Assault; M. Chan, Historiography; Chesneaux, Chinese Labor Movement; Deng, Concise History; Ma, Labor Movement; Morgen, "Chinese Railway Lives"; Sheehan, Chinese Workers; Thomas, Labor and the Chinese Revolution), we have available studies of labor in Shanghai (Isaacs, Tragedy, Walder, Chang Ch'un-ch'iao, Honig, Sisters and Strangers, Perry, Shanghai on Strike, Perry and Li, Proletarian Power, Roux, Grèves et politique à Shanghai, Smith, Like Cattle and Horses); Guangzhou (Canton); and South China (Chan, "Labor and Empire", Dirlik, "Narrativizing Revolution", Kwan, Marxist Intellectuals, Lee, Gender and the South China Miracle), Tianjin (Hershatter, Workers of Tianjin), Changsha (Hunan) (McDonald, Urban Origins; Shaffer, Mao and the Workers), and Chongqing (Sichuan) (Howard, "Workers at War").

These works, moreover, address a broad range of issues. Ma, Labor Movement and Deng, Concise History are works produced by two major labor movement leaders of the Guomindang and the Communist Party, which not only have a great deal to say about the labor movement but also about the effort that went into its organizing and the political struggle over labor. Chesneaux's Chinese Labor Movement is the seminal work on Chinese labor that raised issues which continue to shape studies of labor to this day; it is also emblematic of the teleologies to which I referred above. Honig, Sisters and Strangers and Hershatter, Workers of Tianjin have raised seminal issues on the question of gender, while Honig, Creating Chinese Ethnicity and idem, "Regional Identity" has addressed most directly the question of ethnicity in labor studies. The issue of place has been taken up, in quite different senses, by M. Chan, "Labor and Empire"; Morgan, "Chinese Railway Lives"; Perry, Shanghai on Strike and idem, Putting Class in Its Place; and Dirlik, "Narrativizing Revolution". The question of nationalism is a central question in two recent studies by Howard, "Workers at War", and Smith, Like Cattle and Horses.

I would like to mention in passing one recent work in Chinese which I have been unable to consult, but which is worth referencing here as it may be indispensable in future studies. This is Liu Mingda and Tang Yuliang (eds), Zhongguo gongren yundongshi (History of the Chinese Labor Movement) (Guangzhou, I998). I am grateful to Joshua Howard for this reference. 
of the other. For Chesneaux, it was evidence of the coming of age of the working class in China, which broke with its premodern roots to acquire a fully working-class consciousness, and threw its weight behind the Communist Party in the anti-imperialist and anticapitalist struggle. The study backed up its argument with an impressive body of evidence that ranged across industries over the whole of China, and allowed an account of workers' living conditions, activities and politics that was, and still is, unmatched in comprehensiveness.

While coverage was not restricted to factory workers, factory work was nevertheless crucial to the argument. Chesneaux's argument was fundamentally functionalist in the relationship it established between the mode of production (large-scale industry) and class-consciousness. The functionalism was further driven by a teleology of class-consciousness, and the relationship of class-consciousness to a particular form of politics. Both aspects are quite apparent in the ease with which Chesneaux distinguishes workers who have liberated themselves by becoming proletarian, thereby leaving behind their social and cultural pasts. Having achieved this proletarian consciousness, moreover, they are launched on a new trajectory which can only find its destiny in socialism. The Mechanics' Union in Guangzhou, home to the most advanced workers industrially speaking, nevertheless was the force most hostile to Communist organizers because of the personal relationship of its leader Ma Chaojun to Sun Zhongshan (Sun Yat-sen), and to the Cantonese anarchists. Chesneaux, however, finds a ready-made explanation for such politically "reactionary" behavior in the small-scale machine-shop mentality of Guangzhou mechanics. ${ }^{3}$

If a structural functionalism based on industry is part of the determination, the other is a more "subjective" functionalism that presupposes that class-consciousness must somehow find a home with the Communist Party - and the particular course the communist revolution was to take in China. He writes, "even though the struggles conducted by the Chinese working class between I9I9 and I927 ended in temporary failure, they prepared the way for the crucial change in the center of gravity for the Chinese revolution from the cities to the countryside that occurred in I927". ${ }^{4}$ Not only methodologically but also in the vision that guided the work, The Chinese Labor Movement was universalist in its assumptions. While the concluding pages referred to the "Chineseness" of the Chinese labor movement, the Chinese characteristics that occupied Chesneaux were structural rather than cultural, growing out of China's semicolonial status, the uneven development of capitalism, etc.5 While in the same

3. Chesneaux, Chinese Labor Movement, pp. 203-204.

4. Ibid., p. 410.

5. Ibid., p. 4II. 
breath he does speak of past legacies, he does not elaborate. On the other hand, there is little question about the vision that guided the book, and empowered it. Chesneaux concluded the book with a grand vision that was shared widely by radicals in the I960s,

Thus the Chinese labor movement of 1919-27 belongs at one and the same time to the history of the Chinese revolution, to the history of the whole movement toward emancipation in all the Afro-Asian countries during the twentieth century, and to the history of the fight against capitalism waged over the past century by the workers of the world. ${ }^{6}$

Scholarship on Chinese labor over the last four decades, much of it inspired by and directed at Chesneaux's seminal work, calls for serious qualification of his most basic interpretations. New evidence that became available with the opening of China from the late I970s indicates a much more complicated picture of labor and labor politics. The reading of this evidence, however, has also been informed by new approaches to labor that bore the imprint of a different kind of politics than that which animated Chesneaux's interpretations.

The study of labor in China has been shaped not only by developments within Chinese socialism, but also by the turn labor studies have taken since the I960s. Two developments have been especially important. First has been the abandonment of what we might call a working-class teleology of socialism. Socialists, including revolutionary socialists such as V.I. Lenin, have long questioned the presupposition that working classes are inclined to socialism by virtue of being working-class, but the idea of the working class as the foundation for socialism has had remarkable staying power. So has, conversely, the presumption that actually existing socialist regimes represented working-class interests. The events of the last three decades make it difficult if not impossible to sustain conviction in a mutually enhancing relationship between the working classes and socialism. The disintegration of this conviction is also important, I think, in what we ask and perceive of the past at the present conjuncture.

Even more important may be the abandonment of a teleology of class in favor of a more constructivist understanding that does not infer class formation and consciousness (to be distinguished from consciousness of class) from the structure of economic and social relations, but recognizes the importance of social, political and cultural activity in the making (or unmaking) of class-consciousness. If class-consciousness is not spontaneous, moreover, neither is it homogenous, as the class subject is an overdetermined subject, shaped not just by structural position in the economy but by other aspects of material and cultural existence. In Chinese labor studies, as in the study of labor in general in recent decades, 
gender, place, nationalism and, to a much lesser extent, ethnicity have all been visible in the reconsideration of class as a category. Especially prominent, however, are questions related to place, and to the entanglement of labor in practices inherited from the past. The works discussed below all draw attention to the persistence in modern labor organization and activity of past practices associated with guilds, sisterhoods, and secret societies. Even more important may be questions of native place loyalties and associations (buiguan, translated on occasion as landsmanschaften) which long have been endowed by scholars with crucial significance in understanding Chinese society, as they refer not merely to geographical but also cultural and linguistic differences. The question of native place has drawn renewed ideological power in recent years from the involvement of Chinese overseas in the economic development of the People's Republic of China. How native-place loyalties and associations may have contained, subverted, or shaped class consciousness and activity has been an important question for all of China, but most importantly perhaps for Chinese migrant societies at home (Shanghai and Hong Kong) and abroad. ${ }^{7}$

The complication and historicization of class as a category has led on occasion not only to questioning its conceptual viability, but also its status as a historically significant social and political force. The disintegration of these two teleologies of socialism and class which long informed radical socialist politics, and the place in it of labor, is inextricable from the very question of modernity. It is ultimately the questioning of the teleology of modernity that has rendered salient evidence that was there all along of the persistence of past practices in modern working-class and socialist politics. The waning of the Chinese Revolution, as of revolutions in general, has played an important part in the retreat from modernity as well.

There is a predicament here as there is in all questioning of modernity, Eurocentric as it may be. While the questioning in radical scholarship of the universal claims of modernity has been motivated by the goal of empowering those rendered voiceless under the regime of a Eurocentric modernity, insistence on particularity against universality also has been a weapon in the arsenal of conservatism, itself very much a product of modernity as a reaction to it. The persistence of the past in the present does not necessarily undermine the notion of modernity; but rather than modernity reconfiguring the past as in earlier radical approaches to the problem, recent cultural interpretation has been inclined, quite conserva-

7. The most thorough account of the importance of native places, with reference to Shanghai, is to be found in Goodman, Native Place, City and Nation, although Elizabeth Perry (see below) has done the most in applying it to questions of labor. The literature on native place (buiguan) and clan associations among Chinese overseas is too voluminous to cite here. And little of this work that I am familiar with directly engages questions of class and class-consciousness. 
tively, to capture modernity in past legacies. A curious meeting of minds between Third-World cultural nationalists of various stripes, which now include socialists in retreat from revolution, and putatively radical or liberal First-World anti-Eurocentrists, in retreat from Marxism, has created an intellectual and cultural environment which favors the revival of cultural particularisms ("traditions"), even as it ironically appeals, in doing so, to globalization. Whether or not Chinese labor was "modern" is very much an issue in most discussions of class and socialism, but what is also at issue is the "Chineseness" of Chinese labor. How we answer these questions is not devoid of political inclinations and implications.

The Chinese Labor Movement was published in English translation in 1968, which meant that it landed in the English-speaking world in the context of a new kind of politics in which issues of class were quickly being overtaken by issues of gender, race, and ethnicity. Labor studies were being transformed already by these political developments of the I960s, as well as the publication in 1963 of E.P. Thompson's The Making of the English Working Class, which, along with the works of Eric Hobsbawm, Christopher Hill, Rodney Hilton, etc. gave a much more agent- rather than structure-oriented account of labor history, and underlined the historicity and conditionality of class and class-consciousness. Thompson's assertion that class is not a thing but a relationship pointed both to the "making" of class (and class-consciousness) in the course of everyday life, and the spatial and temporal heterogeneity of the class experience. The "making" of class was a process of achieving a commonly shared language and a commonly shared culture out of social and cultural heterogeneity. Thompson's approach to labor, which sought to replace the imagined labor of theory with historically living labor resonated with an emergent populist tendency, as well as the social and political voluntarism of the I960s. The complexity he introduced into the study of labor was multiplied by the entry of women, ethnicities, and races into the history of labor. The willingness to tamper with theory drew further impetus in these Maoist years from a growing conviction in the necessity of resisting the reduction of Third-World National Liberation struggles into simulacra of First-World theories and concepts. Whatever the elements that went into its making (including fundamentally a revolt against Stalinism), Thompson's work was to exert a seminal influence on the emerging field of Chinese labor studies. ${ }^{8}$

If it is possible to speak of any kind of consensus in Chinese labor studies over the last two decades (when post-Chesneaux studies of labor began to appear), it may be summed up in the words of Alain Roux, himself a student of Chesneaux's: 
We have not encountered the working class, at least not if one ascribes to this term the meaning of a coherent force, conscious of having its own future, organized within structures that it has itself created to promote its interests and capable when the occasion arises of carrying out an effective strike action. 9

Chesneaux drew his conclusions on class formation and consciousness from strike activity by laborers which intensified in the I920s. Later authors, inspired by the new social history, have focused on the phenomena and activity of everyday life, which inevitably reveal serious differences among laborers, that also had obvious implications for strike activity and other expressions of politics. As Gail Hershatter writes of her encounter with the study of labor in Tianjin,

The Tianjin working class was deeply fragmented, with significant numbers of handicraft workers, freight haulers, and casual laborers in addition to the millhands I had hoped to study. The material commanded an attentiveness to fragmentation, divisiveness, a changing sexual division of labor, and growth that proceeded in a distressingly nonlinear fashion. ${ }^{10}$

While authors differ on what they emphasize, the commonly noted differences that divided laborers, and obstructed the fulfillment of class consciousness, were divisions of skill, divisions of gender and age, rural background and the importance of the place of origin, the power exerted by "traditional" organizations such as secret societies, guilds, etc., and the preference of laborers themselves for such organizations against modern labor unions-as with women workers opting for "sisterhoods" over unions. ${ }^{\text {II }}$ These differences were not entirely haphazard, but produced systemic characteristics of their own. Skills and places of origin were closely intervowen, for example, as different places became sources of different kinds of skills. Labor bosses, who in many instances served both as recruiters and managers of labor, oversaw crews of laborers who were from the same locality, spoke the same language, did the same work and shared the same dormitory. Guilds, native place associations, and secret societies, on the other hand, provided institutional sources of power and hierarchy, and contained laborers within imaginary geographical and social spaces that were not particularly conducive to union organization or the generation of class-consciousness. Emily Honig has gone so far as to suggest that secret societies played a major part in shaping the labor system in Shanghai. ${ }^{{ }^{2}}$ It is widely known by now that communist organizers, in order to make progress towards labor organization, had to comply with many of the practices of secret societies - including the drinking of

I I. Honig, Sisters and Strangers, pp. $209-217$.

I 2. Ibid., ch. 5 . 
chicken blood or the swearing of blood brotherhoods. ${ }^{13}$ Skills and place of origin appear as the cornerstones of this system, which produced particularistic loyalties and obstructed the emergence of a universalistic class-consciousness.

Against the claims Chesneaux made for a working class of national scope, later work exhibits a preference for local studies because of significant regional differences in economic practices, the composition of the labor force, and political and cultural relationships. Studies produced over the last two decades have been restricted for the most part to one region or city, with Shanghai receiving by far the greatest attention. This approach almost of necessity favors emphasis on the local roots of labor, and pushes to the background the national and transnational dimensions of labor organization and activity. Regional specificity is important not only for economic (different modes of development) and cultural (different social and symbolic practices, even to mutually incomprehensible languages) reasons, but also because the alignment of social and political forces differed from location to location (as in the loyalty to the Guomindang of the Guangzhou Mechanics' Union, for example, because of a long-standing relationship between Sun Zhongshan [Sun Yat-sen] and the union's leader, Ma Chaojun). ${ }^{14}$ Place of origin plays a very significant part in many explanations of the social and cultural characteristics of Chinese laborers, as well as of their political propensities. Indeed, one author, Elizabeth Perry, endows what she describes as the "politics of place" with the significance to distinguish East Asian from "Western" laborers. She writes,

Although the authors in this volume are engaged in a serious dialogue with that influential paradigm, applying certain of its features to their particular cases, they also emphasize the extent to which worker action in East Asia has been structured along other non-class axes of identity. We discover that educational aspirations, family pressures, gender roles, state directives, native-place origins, and clientelist networks have proven every bit as decisive as class consciousness in shaping the behavior - even the militant behavior - of East Asian workers [...] $[\mathrm{W}]$ orkers in this part of the globe appear to have been more consumed with the politics of "place" - a quest for social and cultural status entailing a desire to elude rather than to embrace, the ranks of the proletariat -than with a "class" struggle to further their interests qua workers. I

Perry's use of "place" in this statement, where place refers to everything from physical to social and political place, is a metaphorization of the more concrete sense in which she uses the concept in her earlier work, Shanghai

I 3. For examples, see Morgan, "Chinese Railway Lives", ch. 7.

I4. For a discussion of these relationships in the case of Guangzhou, see, Ming K. Chan, "Labor and Empire".

I s. Perry, Putting Class in Its Place, p. 3. 
on Strike: The Politics of Chinese Labor, which offers probably the most influential and thorough challenge to Chesneaux's interpretations, possibly because of the intensive original research of the author, as well as her ability to synthesize the findings of earlier works such as those by Honig and Hershatter. Aside from foregrounding skill as a condition of classconsciousness, Perry stressed the importance of place in shaping most workers' behavior and politics. Honig had taken up this point in her study of women workers in Shanghai; in her subsequent work, she convincingly endowed native place with the power to shape ethnic identity. ${ }^{16}$ The power of place in the formation of national and transnational Chinese identities has been addressed since then in the work of Bryna Goodman. ${ }^{17}$

What distinguishes Perry's use in Shanghai on Strike is her positive assessment of place in labor politics; rather than an impediment to the formation of class consciousness - a source of lack, in other words - place was important in serving as the basis for collective action. Perry's argument for place of origin as a source of collective behavior resonates with the argument contra Thompson offered by Craig Calhoun a decade earlier that stressed against class the roles community and tradition played in the production of a coherent labor movement. ${ }^{18}$ Rather than pursue this insight toward a closer examination of the dialectics between places of origin and places of arrival in the production of class-organization and consciousness, Perry in her later work (cited above) has chosen not only to metaphorize this notion of "place", but in the process also to orientalize it as a functional equivalent of Confucianism; as if concern for place appeared in identical ways in East Asian societies, and is absent from other societies, including United States society.

Perry uses politics of place to denote the politics of native place, the way native-place origins continue to shape politics in the place of arrival. This usage is quite different from the use of politics of place in recent radical literature, which contrasts the place-based with the national or global, and seeks to create a place-based politics (at the place of arrival) through local negotiations of difference. Perry's usage, in other words, is informed by the inertia of the other place and the past, which she does not view necessarily as negative, that contrasts with this recent usage that seeks to overcome such inertia without erasing origins. Her idiosyncratic use of the concept enables a privileging of East Asian "differences" but also reveals a bias for origins and the past against the idea of class - which is consistent with conservative trends in contemporary academic work.

A more dynamic notion of place (and class) might have revealed the

I6. Honig, Chinese Ethnicity.

17. Goodman, Native Place, City and Nation.

I 8. Calhoon, Question of Class Struggle. For a suggestion of the relationship of Perry's work to Calhoun's, see, Perry, Shanghai on Strike, p. $25 \mathrm{I}$. 
importance of place in other ways. An identification of class or classconsciousness with national boundaries is merely a prejudice that follows from the premise of the nation as the unit of analysis. Class-consciousness may transcend national boundaries. Class-consciousness may be locally limited and shaped, so that what we call class-consciousness at the broader scope is nothing but a collection of local consciousnesses that may or may not come together in organized collectivities of broader scope - just as class itself may come forward or recede in consciousness as a source of identity depending on circumstances. While places of departure may persist in their effect into places of arrival, they may also vanish or be reconfigured in the new place, or even be transformed by its countereffects. As places may shape classes (or genders or races), they may also be shaped by them. The interplay of places in contemporary global formations raise many questions about class and place; questions that are also pertinent to understanding class formations (or non-formations) before "globalization" or "transnationalism".

The present tendency in studies of Chinese labor, exemplified by Perry, is to stress the "Chineseness" (structural or cultural) of Chinese laborers, which inevitably underlines the roots of the present in the local soil of the past, either in pre-proletarian rural China, or the reconfiguration of the past in the present in the form of secret societies, guilds, etc. Ironically, while this tendency has corrected exaggerated claims to class and class consciousness of an earlier day, it ignores the dynamic elements shaping labor over the years. These same longitudinal studies of Shanghai, Tianjin, Guangzhou, Chongqing all reveal that whatever the obstacles to class formation, and ebbs and flows in the labor movement, Chinese laborers continued to grow in self-consciousness and activity as was evident in the second wave of labor activity on the eve of communist victory. Such laborconsciousness would appear even more dramatically, ironically, in conflicts with the socialist government after 1949 .

A recent work (also on Shanghai) argues that this continued growth was a product of the growing nationalism of the working class. As the author puts it, "it was largely through the discourse of nationalism that workers were empowered to defend their interests as workers". ${ }^{19}$ The author, in making this statement, ignores his own acknowledgment of the varieties of nationalism in the Chinese revolution, and the shaping of nationalism by other discourses, including gender and class. We could say with equal validity that it was through class experiences that Chinese workers understood the discourse of nationalism. Indeed, this may be the case with all the differences in question; gender experience shaped class-consciousness, as class shaped gender, and so on. The phenomena that are being discussed are overdetermined, and can be grasped only with reference to

19. Smith, Like Cattle and Horses, p. 26r. 
one another, and their conjunctural circumstances. At the level of actual strike and political activity, the evidence remains ambiguous: Chinese workers were as ready to strike against Chinese owners as against foreign ones. Some preferred to work for foreigners. War with Japan did not prevent workers from organizing, resistance and strike activity, as has been documented recently by Joshua Howard. ${ }^{20}$

The privileging of nationalism here, as with the privileging of place, is a matter less of conclusive evidence than of a suspicion of class as concept. In much of the work discussed, the criteria for class-consciousness (rarely defined with any precision - for good reasons) are set so high that it would become meaningless to speak of class and class-consciousness anywhere any time. Unless class identity and consciousness have erased all other contestants for social and political identity, there can be no clear or coherent or uncontaminated class formation or consciousness. Once acquired, moreover, class belonging and consciousness are expected to be permanent and stable; evidence of backsliding or hesitation calls class into question, and with it the applicability of class to the experience and activity of Chinese laborers. Such assumptions are basically mirror images of the premises that guided Chesneaux's usage. Recent scholarship has done much to deepen our understanding of labor and class in China. But when it comes to questions of class politics and consciousness, it is hard not to wonder if our choices still are between half-full and half-empty.

A great deal of documentation has become available since The Chinese Labor Movement was written, and much more detailed accounts are available presently on labor conditions and movements in different localities. The Chinese Labor Movement remains unparalleled nevertheless in its grasp of the forces shaping the labor movement at the national as well as the local level. It is important to underline this point because while scholarship on Chinese labor produced in subsequent years has contributed a great deal to our understanding of the complexities of work and workers' consciousness in China, such scholarship often strikes the reader as a qualification, rather than a refutation (as the authors often claim), of Chesneaux's arguments - most importantly because it is localized, and therefore can speak to only part of the national picture. More importantly, what is missing from this work is a sense of the dialectic between the local and the national, and, given the relationship of the national to the transnational in both Chinese economic structures and politics, between the local and the transnational. Awareness of this dialectic shaped the scope of Chesneaux's study, but also brought to it the complexity of interactions between different spatialities and temporalities.

This dialectic between the transnational and the local presupposed the simultaneous existence of the universal and the particular, of an unevenly

20. Howard, "Workers at War". 
developing capitalism, of the city and the countryside under conditions of colonialism and semicolonialism, the impact of all of this on gender relations in the work force, etc. In contrast, studies of labor written in subsequent years - and mostly in response to Chesneaux - appear most importantly as "sinicizing work", efforts at localizing and particularizing labor that, on the one hand, assert the irreducible "Chineseness" of Chinese labor, and, on the other hand, apportion labor into categories of gender, ethnicity, place and nation - to the point where any notion of labor in terms of class and class-consciousness is rendered meaningless.

To use an old metaphor, The Chinese Labor Movement is informed by an awareness not just of trees but also of the forest, while much of later work has done a fine job of tree research, but pretends either that the forest is not there, or deliberately takes it out of the picture. There are serious issues of scholarship involved in making choices of temporal and spatial scope in both research and explanatory strategies employed, but there are also even more serious, and fundamental political choices.

I for one take seriously the vision, the sentiments, and the empirical evidence for them, expressed in the statement above. I have shared tea and cookies with octogenarian revolutionaries only six months after Tiananmen in 1989 , listening to them burst into singing the Internationale and declaring their solidarity with all the oppressed around the world as they recalled the Canton Soviet of December 1927, which for a while made "Red Canton" into the "headquarters of the world revolution". But then, there is the counterevidence, and changing times. In I989, memories of the Canton Commune, and the sixty or so remaining survivors, were all but ignored in the Guangzhou papers devoted to another kind of business. Classes come, and classes go, and politics change, also changing us. Against octogenarian rickshaw pullers singing the Internationale, we have in our days pictures real or imagined of George Bush and Jiang Zemin doing the hula together. It takes a great deal of effort to remember, in only a matter of decades, the vision that drove The Chinese Labor Movement.

The vision that guided Chesneaux is crucial to a critical evaluation of the globalization mania that now has replaced modernization as a way of erasing the past, but imagining Bush and Jiang doing the hula is also helpful in historicizing that vision. Not many historians of labor in China would object that there was a surge of class politics and consciousness in the I920s, again in the I940s, I960s, and I980s to the present. On the other hand, class politics is not equally salient in every part of China at all times. The most significant labor movement in Chinese politics, from ig25 to 1927, started in Shanghai, but culminated in Guangzhou, where it was brought to a tragic end in December 1927 by widespread massacres. The local warlord who butchered laborers became a member after I949 of the Political Consultative Conference, as a representative of the Revolutionary Guomindang, presumably because he was at odds with Jiang Jieshi 
(Chiang Kai-shek). Such vagaries in the politics of labor do not lend themselves to easy structural explanations.

Like the concept of globalization that has replaced it, the problem with a Marxist internationalism such as that of Chesneaux's is its refusal to acknowledge a sense of contradiction; that the local, the national and the global do not all point in the same direction, but in contradictory directions, and that we have to account for them in their contradictory overdeterminedness, which makes judgment about their progressiveness much more complicated than he allows. In terms of explanatory strategy, the vision makes for a functionalist account of labor that does not so much explain "real, living" laborers, as assign to them their places in terms of class-consciousness and the struggle toward socialism.

On the other hand, while attention to "real, living" laborers perhaps complicates class to the point of meaningless, we need to consider the consequences of abandoning the concept. In the first place, emphasis on everyday life, or a radical historicism of any kind, militates against the possibility of capturing the subjects of history not just in class but in any collective conceptual category; gender, too, for instance becomes meaningless when it is "placed" into so many locations of origin of women workers. The latter shows cogently the pitfalls of a historicist denial of conceptual approaches to history, since there obviously women workers whose experiences differed from male workers even though they may have been divided internally. Same goes for class, which may have been riven by so many intersections of physical and social identity, but is essential nevertheless to understanding certain structural divisions in society, and increasingly shaped social and political discourse - and, with it, the behavior of many. What is remarkable is the obliviousness of much of existing scholarship to the evidence that it has brought to light: that class activity and consciousness intensified with industrialization and the accumulation of experience. While class activity was minimal in the I930s, due to the hostility of the Guomindang government to issues of class, it picked up again during the years of war and civil war (1937-I949), and continues unabated to this day. It is testimonial to the closed world of scholarship that while the youthfulness of the urban working class in China in the I920s is widely acknowledged by all sides, the opposing interpretations offered seem to gloss over the importance of this evidence in debates over whether or not this burgeoning working class broke immediately (and somewhat miraculously) with its past as it moved from village to factory, or whether it was mired in past social restrictions and cultural practices no matter how many worlds of production, social life, and political activity it traversed.

Scholarship on labor in European societies, produced during this same period, including Thompson's, also has revealed that the first generation(s) of laborers was steeped in "preproletarian" and "premodern" forms of 
behavior, and had an ambivalent attitude toward labor activity. ${ }^{21}$ It goes without saying that Chinese workers brought into their proletarian experience locally formed social and cultural practices, as did French, British, German, or Japanese workers; which is a reminder that the discourse of class, no less than its experience, is not only nationally but locally diverse. It is much more problematic to suggest, however, that the dynamics of social transformation were, therefore, different from one to another cultural sphere; or that local forces that shaped the experience and discourse of class retained the binding force they had earlier, immune to the transformative effects of the new social and discursive fields in which they were relocated. And, of course, as I have suggested already, even acquiring a fully developed class-consciousness (very problematic in the assumption that life can be reduced to class issues) is no guarantee that class will not lose its saliency for individual and societies as times change and social structures are transformed - to which our own day may serve as testimonial. It is worth quoting at some length, one of the authors most sensitive to these questions, Gail Hershatter, who cogently captures the uncertainties of a working class in formation in her conclusion to her study of labor in Tianjin:

$[\ldots]$ it seems clear that what mobilized workers in periods of action was not an abstract commitment to a revolutionary ideology, but the concrete possibility of doing something about the immediate conditions of their working lives [...]. Did Tianjin workers, as E.P. Thompson has put it, "as a result of common experiences (inherited or shared), feel and articulate the identity of their interests as between themselves, and as against other men whose interests are different from (and usually opposed to) theirs"? Sometimes. Tianjin workers saw themselves as rooted in a variety of relationships. Some represented continuity with their rural past, some the search for survival in the workplace. Those networks could be put to a variety of uses; securing cross-class protection was one, and forging alliances for change was another. "Common experiences" and "identity of interests" did not always seem to organize themselves along class lines. When they did, then workers articulated their own interests against not only those of the factory owners but of the government. But this perception of interests as structured by class was situational, and therefore transient in the constantly changing political environment of Tianjin. ${ }^{22}$

We will never know how the working class in China might have developed in the long run had it not been for the victory of the Communist Party in I949. Its post-I 949 development presents its own contradictions. The working class arguably came into full consciousness of itself under a regime directed by a party that viewed itself as the vanguard of the working class. On the other hand, the new regime created divisions of its

21. For influential examples for French labor, see William Reddy, The Rise of Market Culture, and William Sewell, Work and Revolution in France.

22. Hershatter, Workers, pp. 239-240. 
own among the working class by favoring a skilled working class mostly working in state factories ${ }^{23}$ (Walder, 1988). For all its claims to representing the working class, moreover, the Party in state power had its own agenda of national development, not to speak of party interests in state power, that were often antagonistic to worker interests and expectations. The divergence, and the conflict, which has become widespread and quite sharp in recent years, go back to the origins of the new regime, and maybe even earlier.

\section{THE PARTY AND THE WORKING CLASS}

If Chesneaux's The Chinese Labor Movement is a Marxist classic which in hindsight is shaped and limited by its acquiescence in the teleology of the Communist Party's rise to power, it has a counterpart in another classic that saw in the trajectory of the revolution in the late I920s the betrayal of the Chinese working class. Harold Isaacs's The Tragedy of the Chinese Revolution is not a scholarly work such as Chesneaux's, but shares with it passionate political engagement, this time in a Trotskyist perspective. It derives its power from an epic depiction of the rise of the working class in China, which was already prepared to take power in its hands, but was betrayed by its communist leaders, and ultimately by Stalin who dictated the course of the revolution, and the defeats of I 927 . At least for the I920s, it not also shares with Chesneaux's work a conviction that a modern working class had already come into existence by the mid-I 920 , but goes further to suggest that this working class had the maturity to take the leadership in socialist revolution.

That there was betrayal at work in the I920s is not open to much doubt, though what choices either the Chinese communist leadership or Stalin had in 1927 against the betrayal of the generals remains an open question. The Party on occasion also blamed workers for its own mistakes; as it did after the abortive Guangzhou Uprising of December 1927, the finale of the urban revolution of the I920s, when an event that had been planned by party leadership with advice from Soviet advisors was blamed after the defeat on the failure of grassroots working-class cadres. ${ }^{24}$ But some of the criticism directed against Chesneaux is valid also in the case of Isaacs. Isaacs, too, is carried away by a vision of the working class in revolution, and overlooks the difficulties the working class presented to revolutionary Party organizers who were quite dedicated as communists to workingclass liberation. Communists had to struggle against secret society, guild, and native place associations, which not only had controlling power on workers, but often also commanded their loyalty. They had to instill in

23. For a discussion of this problem, see, Andrew Walder, Communist Neo-traditionalism.

24. Arif Dirlik, "Narrativizing Revolution", and, Daniel Kwan, Marxist Intellectuals. 
laborers' minds, fashioned in local origins, not only an awareness of class but also a class-consciousness that would help overcome inherited social and cultural prejudices. Perhaps the greatest problem was what socialist leadership might have meant to an emergent working class such as this one, if it was not mediated from the outside; we might say at the least that if socialism of some kind could have emerged out of the revolutionary mobilization of workers in the I920s, it would have been a very different socialism than the one Isaacs had in mind.

Nevertheless, Trotkyists such as Isaacs and other radical critics of the Chinese Bolsheviks such as the anarchists, insisted from the beginning on a conflict of interest between the workers, and a centralist party claiming working-class leadership. This conflict would become much more important after 1949. As noted above, the legitimation of the Communist regime as the vanguard of the working class, and the protections extended to laborers, not to speak of class as the dominant social, political and cultural paradigm, created both an unprecedented environment for the formation and organization of the working class on a country-wide basis, but also for the nurturing of consciousness of class as well as class consciousness. On the other hand, workers were divided, with only a minority benefitting directly from the new regime while the majority had access neither to political power or economic benefits. The working class as a whole obviously did command considerable power and privilege as compared to most capitalist societies, but their minimal power was conspicuously incommensurate with the powerful part the idea of the working class played in legitimizing Part rule. The Party, having abolished "classes", even declared on occasion that there was no working class in China, because the laws of the dialectic demanded that there could be no working class unless there was also a bourgeoisie - which in China had ceased to exist. This, of course, served as a convenient excuse for not allowing independent trade unions.

Recent work suggests that these contradictions led to conflict between workers and the Party from the beginning of the regime. A recent study suggests that almost every "turning point" in Chinese politics (urban reform, to the Great Leap, Cultural Revolution, Deng Xiaoping reforms, and all the way to the present), also has been an occasion for labor insurgency; which has received little attention from scholars preoccupied with political and ideological issues. ${ }^{25}$ Perhaps the most dramatic moment of the Cultural Revolution was the Shanghai Commune established by insurgent workers in January $1967 .{ }^{26}$

25. See Jackie Sheehan, Chinese Workers, for an interesting study of political upheavals and labor unrest in post-I 949 China.

26. For discussions of Shanghai during the Cultural Revolution of the ig6os, see, Elizabeth Perry and Li Xun, Proletarian Power; Andrew Walder, Chang Ch'un-ch'iao. 
The Tiananmen Incident of June 1989 was to play an important part in bringing to the foreground Party-labor conflict, even though few at the time paid close attention to the calls for "autonomous" labor unions, or to the workers killed on June 4 who were at the forefront of street-fighting, and provided the majority of the victims. Even more important in the long run may be increasing evidence of severe abuse and exploitation of workers, accompanied by increasingly pervasive labor unrest. The much ballyhooed economic development of China with "globalization" has been made possible by a severe exploitation of labor, the progressive abandonment by the state of its labor protections, especially in the Special Economic Zones, and even the export of slave-like labor. ${ }^{27}$ China may not be very different in these regards from other so-called contemporary developing societies; the irony there is the use of socialist language to keep labor in its economic and social "place". Laborers are obviously not fooled, as judged both by intense labor activity, and the response of labor leaders to Party ideological manipulation. Chinese laborers have come a long, long way.

\section{CHINESE LABOR HISTORY AND GLOBALIZATION}

I would like to end here with a few thoughts on some of the contemporary relevance of the issues discussed above. Much of the literature discussed above was written in response to Marxist accounts of Chinese labor by Chinese communists, as well as Euro-American Marxists such as Chesneaux and Isaacs. Most of this literature is not anti-Marxist in intention, but seeks rather to understand class relations in more complicated ways, which on occasion is carried to the point where it becomes meaningless to speak of class as a concept. This has pretty much become the case in recent years, as this literature is dissolved into an intellectual environment where other concerns have overtaken, and overshadowed, consciousness of classes. It has become difficult also to identify classes as social phenomena because of the blurring of all kinds of boundaries, which also makes it difficult if not impossible to determine the boundaries of class as concept or social phenomenon. Whether or not there

27. See the collection of documents in Anita Chan, China's Workers. My use of "slave" labor needs to be distinguished from right-wing criticism of labor in the People's Republic of China, such as that of US Senator Jesse Helms (Republican - NC). Helms and those of his ilk focus on such phenomena as prison labor, conveniently overlooking the severe exploitation and mistreatment of labor in regular factory work under the regime of global capitalism (and that prison labor itself is not just a Chinese phenomenon, as it is used widely in the United States). In the case of the PRC, official collusion with foreign capital facilitates such exploitation, while socialism serves as an ideological excuse to undercut the ability of labor to organize for selfprotection. Hong Kong and Taiwan entrepreneurs, in collusion with local officials, would seem to be the worst, if not the only, abusers of labor. For a study of the condition of migrant Chinese labor in the United States, see, Peter Kwong, Forbidden Labor. 
is such a thing as globalization, there is an intensification of translocal activity, which deprives us also of the security of conceiving working classes in national terms.

The issues raised above, in particular issues of place and class, may be quite significant in their relevance to a contemporary situation - if only there is a problem once again of relating class to place. The present is a period when, more than ever before, class formations are becoming globalized or transnationalized, and call for organization at supranational levels. At the same time, there is a concern for local, or place-based, welfare at the infranational level, as has been evident in antiglobalization mobilization. Class still offers a way of critically grasping the interconnections of the global, the national, and the place-based. On the other hand, such a situation demands that we think of class formations at a number of levels also, in their conjunctural multiplicity, rather than in their mutual exclusiveness.

There is another, more "practically" oriented, aspect to this question in reference to a place like Shanghai, that also brings to the foreground the significance of places of arrival against places of departure. Shanghai was an immigrant city, and its laboring force was an immigrant force. While immigration to Shanghai continues, the often cited insider/outsider Shanghai mentality seems to continue in full force - which suggests that over a century, a full-blown Shanghai identity and culture was forged out of differences in local activities and interactions. This Shanghai identity includes the Shanghai working class, conscious of itself as Shanghai'ese. How did this come about? It is difficult to find answers to this question in studies that overwhelmingly lean in preference to places of departure over places of arrival. It is nevertheless an important question in understanding the emergence of a working class that could be strongly class, Shanghai, nation, and global conscious all at the same time. It may have considerable relevance to a contemporary global predicament, as migrants flow to nodes of capitalist activity, which Shanghai was, and is. Other locations in China present other possibilities; as in the case, for instance, with Guangzhou (Canton) which, for a while became the "Paris Commune of the East", as Shanghai had been dubbed the Paris of the East, and symbolized a "headquarters" of world revolution. It shaped, as well as was shaped by, the British colony of Hong Kong right down the road, and its laborers partook of a culture that cut across the boundary between the province and the colony; offering another instance of the class/place dialectic, that may be relevant in our day in different ways (Israel/Palestine, for example).

To return to a suggestion I made earlier, as later work has revealed much about the shortcomings of earlier, Marxist-driven studies of labor, those earlier works also offer a much-needed source of critical perspective on the present (not to speak of their continued value as scholarship). The point now is not to substitute class for place or place for class, but to open up a 
field of their dialectics, not only with one another but with a whole multiplicity of social identity markers; to work toward the mutual articulations of these identity markers without erasing their differences from one another. Debates in Chinese labor history have been quite valuable in forcing to the forefront issues that once again confront us at a larger scale in a postsocialist world.

\section{B IB L IO G R A PHY}

BIAN YANJIE Work and Inequality in Urban China (Albany, NY, I994).

Calhoun, Craig The Question of Class Struggle: Social Foundations of Popular Radicalism during the Industrial Revolution (Chicago, IL, I982).

Chan, Anita China's Workers Under Assault: The Exploitation of Labor in a Globalizing Economy (Armonk, NY, 200I).

Chan, Ming K. "Labor and Empire: The Chinese Labor Movement in the Canton Delta, I895-1928”, (unpublished Ph.D. dissertation, Stanford University, CA, 1975).

Chan, Ming K. Historiography of the Chinese Labor Movement, I895-1949: A Critical Survey and Bibliography (Stanford, CA, I981).

Chesneaux, Jean The Chinese Labor Movement, 1919-1927, transl. from the French by H.M. Wright (Stanford, CA, I968). French original published in 1962.

Deng ZhongXia Zhongguo zhigong yundong jianshi, 1919-1926 (A Concise History of the Chinese Labor Movement) (Hong Kong, 1978, first published 1943). Author's preface dated 1930 .

DirliK, ArIF The Origins of Chinese Communism (New York [etc.], I989).

DirliK, Arif Anarchism in the Chinese Revolution (Berkeley, CA [etc.], I99I).

Dirlik, Arif "Narrativizing Revolution: The Guangzhou Uprising (I I-I 3 December 1927) in Workers' Perspective", Modern China, 23 (1997), pp. 363-397.

Goodman, Bryna Native Place, City and Nation: Regional Networks and Identities in Shanghai, I853-1957 (Berkeley, CA, 1995).

Hammond, Edward R. "Organized Labor in Shanghai, I927-1937”, (unpublished Ph.D. dissertation, University of California at Berkeley, CA, 1978).

Hershatter, Gail The Workers of Tianjin, I900-1949 (Stanford, CA, I986).

Honig, Emily Sisters and Strangers: Women in the Shanghai Cotton Mills, 19191949 (Stanford, CA, 1986).

Honig, Emily Creating Chinese Ethnicity: Subei People in Shanghai, I850-1980 (New Haven, CT, 1992).

Honig, Emily "Regional Identity, Labor and Ethnicity in Contemporary China", in Elizabeth J. Perry (ed.), Putting Class in Its Place: Worker Identities in East Asia (Berkeley, CA, I996), pp. $225-243$.

Howard, Joshua H. "Workers at War: Labor in the Nationalist Arsenals of Chongqing, I937-I949”, (unpublished Ph.D. dissertation, University of California at Berkeley, CA, 1998).

Isaacs, Harold R. The Tragedy of the Chinese Revolution (Stanford, CA, I96r). Originally published in 1938 .

Kwan, Daniel Marxist Intellectuals and the Chinese Labor Movement: A Study of Deng Zhongxia, I894-1933 (Seattle, WA, I997). 
Kwong, Peter Forbidden Workers: Illegal Chinese Immigrants and American Labor (New York, I997).

Lee, Ching Kwan Gender and the South China Miracle: Two Worlds of Factory Women (Berkeley, CA, I998).

Lee, Ching Kwan "Pathways of Labor Insurgency", in Elizabeth J. Perry and Mark Selden (eds), Chinese Society: Change, Conflict and Resistance (London [etc.], 2000), pp. 4I-6I.

Liu Mingda and TANg Yuliang (eds) Zhongguo laodong yundongshi (History of the Chinese Labor Movement) (Guangzhou, I978).

Ma Bin and Han Yaxi "Letter", Monthly Review, 2002.

Ma Chaojun Zhongguo laogong yundong shi (History of the Chinese Labor Movement), 5 vols (Taibei, Republic of China, 1959), first published in 1947.

McDonald, Angus W., Jr The Urban Origins of Rural Revolution: Elite and the Masses in Hunan Province, China, I9II-I927 (Berkeley, CA, I978).

Morgan, Stephen L. "Chinese Railway Lives, i9i2-i937", (unpublished Ph.D. dissertation, Australian National University, Canberra, I995).

Perry, Elizabeth J. (ed.) Shanghai on Strike: The Politics of Chinese Labor (Stanford, CA, I993).

Perry, Elizabeth J. (ed.) Putting Class in Its Place: Worker Identities in East Asia (Berkeley, CA, I996).

Perry, Elizabeth J. and Li Xun Proletarian Power: Shanghai in the Cultural Revolution (Boulder, CO, I995).

Reddy, William M. The Rise of Market Culture: The Textile Trade and French Society (New York, I984).

Roux, Alain “Le Mouvement ouvrier à Shanghai de 1928 à I 930 ”, (Thèse à troisième cycle, Sorbonne, Paris, I970).

Roux, Alain Le Shanghai ouvrier des années trente: Coolies, Gangsters et Syndicalistes (Paris, I993).

Roux, Alain Grèves et politique à Shanghai: Les désillusions (1927-1932) (Paris, I995).

Sewell, William H. Work and Revolution in France: The Language of Labor from the Old Regime to I 848 (New York, i980).

Shaffer, Lynda N. Mao and the Workers: The Hunan Labor Movement, I920-1923 (Armonk, NY, I982).

Sheehan, Jackie Chinese Workers: A New History (London, I998).

SмIтH, S.A. Like Cattle and Horses: Nationalism and Labor in Shanghai, I 895-1927 (Durham, NC, 2002).

Thomas, S. Bernard Labor and the Chinese Revolution (Ann Arbor, MI, I983).

Walder, Andrew G. Chang Ch'un-ch'iao and Shanghai's January Revolution (Ann Arbor, MI, I978).

Walder, Andrew G. Communist Neotraditionalism: Work and Authority in Chinese Industry (Berkeley, CA, I988). 